\title{
Physicochemical, Thermal and Spectroscopic characterization of the Energy of Consciousness Healing Treated Copper Chloride
}

\author{
Trivedi $\mathrm{MK}^{1}$ and Jana $\mathrm{S}^{2 *}$
}

${ }^{1}$ Trivedi Global, Inc, USA

${ }^{2}$ Trivedi Science Research Laboratory Pvt Ltd, India

ISSN: 2578-0255

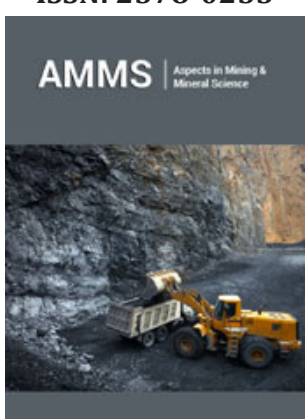

*Corresponding author: Snehasis Jana, Trivedi Science Research Laboratory Pvt Ltd, Thane (West), Maharashtra, India

Submission: 洒 January 18, 2021

Published: 侮February 09, 2021

Volume 6 - Issue 2

How to cite this article: Trivedi $\mathrm{MK}$ Jana S, Physicochemical, Thermal and Spectroscopic characterization of the Energy of Consciousness Healing Treated Copper Chloride. Aspects Min Miner Sci. 6(2). AMMS. 000633. 2021.

DOI: 10.31031/AMMS.2021.06.000633

Copyright@ Trivedi MK, This article is distributed under the terms of the Creative Commons Attribution 4.0 International License, which permits unrestricted use and redistribution provided that the original author and source are credited.

\begin{abstract}
Copper is the essential trace mineral that acts as a cofactor for enzyme systems related with the red blood cell formation, iron transport and metabolism, and immune function. The aim of this study was to determine the effect of The Trivedi Effect ${ }^{\circledR}$-Energy of Consciousness Healing Treatment on the physical, thermal, and spectral properties of copper chloride. In this study, the copper chloride sample was divided in two parts, in which one part was kept untreated and termed as control sample. Another part was termed as Biofield Energy Treated sample and it was treated remotely with The Trivedi Effect ${ }^{\circledR}$-Biofield Energy Healing Treatment by the renowned Biofield Energy Healer, Mr. Mahendra Kumar Trivedi. Consequently, both the samples were analyzed with the help of PXRD, TGA/DTG, DSC, UV-Vis, and FT-IR analytical techniques. The PXRD analysis of the treated sample showed the significant changes in the relative peak intensities and crystallite sizes from $-27.67 \%$ to $153.49 \%$ and $0.126 \%$ to $30.03 \%$, respectively along with $4.49 \%$ decrease in average crystallite size compared with the control sample. Besides, The TGA/DTG analysis showed that the weight loss of Biofield Energy Treated sample in $1^{\text {st }}, 2^{\text {nd }}$, and $3^{\text {rd }}$ step was altered by $0.33,-17.79$, and $3.64 \%$, respectively, along with $1.45 \%$ increased total weight loss as compared to the control sample. The treated sample also showed significant increase in the maximum degradation temperature $\left(\mathrm{T}_{\text {max }}\right)$ for every peak by $6.92,1.32$, and $1.77 \%$, respectively, compared to the control sample. The DSC analysis revealed that the melting point of the treated copper chloride was slightly reduced by $1.31 \%$ with a reduced latent heat of fusion $(\Delta \mathrm{H})$ by $3.78 \%$ compared to the control sample. However, the decomposition temperature of the treated sample was increased by $9.12 \%$ with a significant reduction of the enthalpy of decomposition by $43.45 \%$ compared with the control sample. Moreover, the FT-IR studies also revealed some alterations in the spectrum of the treated sample, as the peaks at 892 and $1154 \mathrm{~cm}^{-1}$ in the control spectra were not observed in the treated sample and the peak at $1588 \mathrm{~cm}^{-1}$ in the control sample spectra was shifted to higher frequency at $1601 \mathrm{~cm}^{-1}$ in the spectra of treated sample. The overall study represents that The Trivedi Effect ${ }^{\circledR}$-Energy of Consciousness Healing Treatment may help in the production of a polymorphic form of copper chloride, which would be having better bioavailability and improved thermal stability compared to the control sample.
\end{abstract}

Keywords: Copper chloride; The Trivedi effect ${ }^{\circledR}$; Energy of consciousness healing treatment; PXRD; FTIR; DSC; TGA

Abbreviations: NCCIH: National Center of Complementary and Integrative Health; PXRD: Powder X-Ray Diffraction; TGA: Thermo Gravimetric Analysis; DSC: Differential Scanning Calorimetry; DTG: Differential Thermogravimetric Analysis

\section{Introduction}

Copper is considered as the essential trace mineral as it is the important component for the enzyme systems involved in red and white blood cell formation, iron transport and metabolism, and immune function. It acts as a cofactor for serum ceruloplasmin, which is vital for proper formation of the iron carrier protein, transferring [1]. The copper is also given during TPN that helps in preventing the deficiency symptoms such as, anemia, leukopenia, decreased ceruloplasmin levels, neutropenia, secondary iron deficiency, impaired transferrin formation, and osteoporosis [2]. It is also needed in the body regarding the function of several proteins, such as, ceruloplasmin, superoxide dismutase, cytochrome c oxidase, dopaminebeta-hydroxylase, lysyl oxidase, and tyrosinase. Moreover, it helps the body to use the iron and sugar and plays important role in nerve function and bone growth [3]. The body also required it for the normal growth and health [4]. Copper can be combined easily with other metals to make alloys. The first alloy produced was copper melted with tin to form bronze. 
Copper and copper alloys are tough and suitable to use for tools and weapons [5]. Copper is non-magnetic and non-sparking. Due to this properties, it is used in special tools and military applications $[6,7]$. The natural sources of copper include seafood, organ meats (mainly liver), beans, whole-grains, and nuts. However, its quantity may be decreased if the foods are high in their acid content or if they were stored in tin cans for a long time. In past decades, several studies gave the concept that the copper deficiency may contribute to the development and progression of various diseases such as, cardiovascular disease and diabetes $[8,9]$. Also, the systemic copper deficiency is responsible for producing the cellular iron deficiency that resulted in the reduced intellectual capacity, decreased work capacity, diminished immune response, reduced growth, and altered bone mineralization process [10]. Copper deficiency may cause the structural malformations in the child during early pregnancy and may also create the immunological and neurological abnormalities in the fetus $[11,12]$. Besides, there are some conditions that may increase the need of copper within the body, such as, intestine disease, burns, pancreas disease, diarrhoea, kidney disease, stress, and stomach removal, etc. Thus, the copper supplements are necessary for those persons who are unable to get the required quantity through their regular diet or those having some specific conditions [13]. Copper Chloride is indicated as a copper supplement, which helps in maintaining its level and preventing the depletion of endogenous stores and thereby the resulted deficiency symptoms. In recent days, the Biofield Energy Treatment has been considered as an effective approach for altering the absorption and bioavailability as well as stability profile of any compound.

The use of complementary therapies such as Biofield Energy Healing has been widespread in US, UK, and other countries and their significant clinical outcomes have been increased every year $[14,15]$. However, mainstream medicines have been found to be inconclusive and not able to show the significant outcomes [16-18]. Biofield Energy exists in various forms that can be produced from various sources like potential, electrical, kinetic, magnetic, and nuclear energy. The Biofield Energy is infinite, para-dimensional, and dynamic electromagnetic field surrounding the human body that produce the continuous movement of matter or energy [19]. Thus, a human has the ability to harness energy from the earth and transmit it to any living or non-living object(s) around the globe [20]. The National Center of Complementary and Integrative Health (NCCIH) has been recognized and accepted Biofield Energy Healing as CAM health care approach in addition to other therapies, medicines and practices such as natural products, deep breathing, yoga, Tai Chi, Qi Gong, chiropractic/osteopathic manipulation, meditation, massage, special diets, homeopathy, progressive relaxation, guided imagery, acupressure, acupuncture, relaxation techniques, hypnotherapy, healing touch, movement therapy, Pilates, Rolfing structural integration, mindfulness, Ayurvedic medicine, traditional Chinese herbs and medicines, naturopathy, essential oils, aromatherapy, Reiki, cranial sacral therapy and applied prayer (as is common in all religions, like Christianity, Hinduism, Buddhism and Judaism) [21]. The Trivedi Effect ${ }^{\circledR}$ Biofield Energy Consciousness Healing Treatment has astonishingly ability to transform the characteristic properties of several organic compounds [22-25], pharmaceuticals [26,27], nutraceuticals [28], metals and ceramic $[29,30]$, culture medium $[31,32]$ and improve the overall productivity of agricultural crops [33,34], skin health $[35,36]$, modulation in the efficacy of various living cells [3739], and alteration of the isotopic abundance ratio in the organic compounds [40-43]. Thus, this study was designed to analyses the impact of Biofield Energy Treatment (The Trivedi Effect ${ }^{\circledR}$ ) on the physicochemical, thermal, and spectroscopic properties of copper chloride by using various analytical techniques such as, powder X-ray diffraction (PXRD), thermogravimetric analysis (TGA), differential scanning calorimetry (DSC), UV-visible, and FT-IR spectroscopy.

\section{Materials and Methods}

\section{Chemicals and reagents}

Copper (II) chloride or cupric chloride was purchased from VETEC, Sigma-Aldrich, India. All other chemicals used during the experiments were of analytical grade available in India.

\section{Consciousness energy healing treatment strategies}

The test compound i.e., copper chloride was taken and divided into two parts. In this, one part did not receive the Biofield Energy Treatment and named as control copper chloride. Besides, the other part of the test compound received the Energy of Consciousness Healing Treatment by the renowned Biofield Energy Healer, Mr. Mahendra Kumar Trivedi (USA), and it was considered as the Biofield Energy Treated copper chloride. In this process, the sample was placed under the standard laboratory conditions and the Healer provided the Trivedi Effect ${ }^{\circledR}$-Energy of Consciousness Healing Treatment to the sample, remotely, for 3 minutes through the Unique Energy Transmission process. Consequently, the control sample was subjected to "sham" healer under the similar laboratory conditions, who did not have any knowledge about the Biofield Energy Treatment. Later on, the control and Biofield Energy Treated samples were kept in similar sealed conditions and characterized with the help of PSA, PXRD, TGA/DTG, DSC, UV-Vis, and FTIR techniques.

\section{Characterization}

Powder X-ray diffraction (PXRD) analysis: The PXRD analysis of control and Biofield Energy Treated samples of copper chloride was done using PANalytical X'Pert3 powder X-ray diffractometer, UK. The copper line was used as the source of radiation for diffraction of the analyte at $0.154 \mathrm{~nm} \mathrm{X-ray} \mathrm{wavelength} \mathrm{that} \mathrm{is} \mathrm{running} \mathrm{at} 40 \mathrm{~mA}$ current and $45 \mathrm{kV}$ voltage. The instrument uses a scanning rate of $18.87^{\circ} /$ second over a $2 \theta$ range of $3-90^{\circ}$ and the ratio of $\mathrm{K} \alpha-2$ and $\mathrm{K} \alpha-1$ was 0.5 (k, equipment constant). The data was collected using X'Pert data collector and X'Pert high score plus processing software

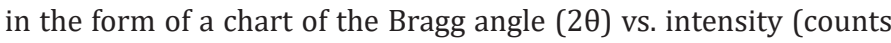


per second), and a detailed table containing information on peak intensity counts, $d$ value $(\AA)$, full width half maximum (FWHM) $\left({ }^{\circ} 2 \theta\right)$, relative intensity (\%), and area (cts*o $2 \theta$ ). The crystallite size $(G)$ was calculated by using the Scherrer equation (1) as follows:

$$
G=\frac{k \lambda}{(b \operatorname{Cos} \theta)}
$$

Where, $\mathrm{k}$ is the equipment constant $(0.5), \lambda$ is the $\mathrm{X}$-ray wavelength $(0.154 \mathrm{~nm})$; $b$ in radians is the full-width at half of the peaks and $\theta$ is the corresponding Bragg angle. Percent change in crystallite size $(G)$ of copper chloride was calculated using following equation 2:

$$
\% \text { changeincrystallitesize }=\frac{\left[G_{\text {Treated }}-G_{\text {Control }}\right]}{G_{\text {Control }}} \times 100
$$

Where, $G_{\text {Control }}$ and $G_{\text {Treated }}$ are the crystallite size of the control and Biofield Energy Treated copper chloride samples, respectively.

\section{Thermal gravimetric analysis (TGA)/differential} thermogravimetric analysis (DTG): TGA/DTG thermograms of control and Biofield Energy Treated copper chloride samples were obtained using TGA Q500 thermo analyzer apparatus, USA under dynamic nitrogen atmosphere $(50 \mathrm{~mL} / \mathrm{min})$. It involves the heating rate of $10{ }^{\circ} \mathrm{C} / \mathrm{min}$ from $25^{\circ} \mathrm{C}$ to $800{ }^{\circ} \mathrm{C}$ and uses platinum crucible [41]. In TGA analysis, the weight loss in gram as well as percent loss for each step was recorded with respect to the initial weight of the sample. Later on, in DTG analysis, the onset, end set, peak temperature and integral area for each peak was recorded. The percent change in weight loss $(\mathrm{W})$ was calculated using following equation 3:

$$
\% \text { changeinweightloss }=\frac{\left[W_{\text {Treated }}-W_{\text {Control }}\right]}{W_{\text {Control }}} \times 100
$$

Where, $\mathrm{W}_{\text {Control }}$ and $\mathrm{W}_{\text {Treated }}$ are the weight loss of the control and Biofield Energy Treated samples, respectively.

Also, the percent change in maximum thermal degradation temperature (Tmax) (M) was calculated using following equation 4:

$$
\% \text { changein }_{\max }(M)=\frac{\left[M_{\text {Treated }}-M_{\text {Control }}\right]}{M_{\text {Control }}} \times 100
$$

Where, $\mathrm{M}_{\text {Control }}$ and $\mathrm{M}_{\text {Treated }}$ are the Tmax values of the control and Biofield Energy Treated samples, respectively.

Differential scanning calorimetry (DSC): The DSC analysis of the samples was performed using DSC Q2000 differential scanning calorimeter, USA under the dynamic nitrogen atmosphere with flow rate of $50 \mathrm{~mL} / \mathrm{min}$. For analysis, $2-4 \mathrm{mg}$ sample was weighed and sealed in Aluminum pans. Further, it was equilibrated at $30^{\circ} \mathrm{C}$ and heated up to $450^{\circ} \mathrm{C}$ at the heating rate of $10^{\circ} \mathrm{C} / \mathrm{min}$ under Nitrogen gas as purge atmosphere [44]. The value for onset, end set, peak temperature, peak height ( $\mathrm{mJ}$ or $\mathrm{mW}$ ), peak area, and change in heat
$(\mathrm{J} / \mathrm{g})$ for each peak was recorded. Later on, the percent change in melting temperature (T) of the control and Biofield Energy Treated samples was calculated using following equation 5 :

$$
\% \text { changeinmeltingtemperature }=\frac{\left[T_{\text {Treated }}-T_{\text {Control }}\right]}{T_{\text {Control }}} \times 100
$$

Where, $\mathrm{T}_{\text {Control }}$ and $\mathrm{T}_{\text {Treated }}$ are the melting temperature of the control and Biofield Energy Treated copper chloride samples, respectively. Also, the percent change in the latent heat of fusion $(\Delta \mathrm{H})$ was calculated using following equation 6 :

$$
\% \text { changeinlatentheatoffusion }=\frac{\left[\Delta H_{\text {Treated }}-\Delta H_{\text {Control }}\right]}{\Delta H_{\text {Control }}} \times 100
$$

Where, $\Delta \mathrm{H}_{\text {Control }}$ and $\Delta \mathrm{H}_{\text {Treated }}$ are the latent heat of fusion of the control and treated copper chloride, respectively.

Ultraviolet-visible spectroscopy (UV-Vis) analysis: The UV-Vis spectral analysis of the control and Biofield Energy Treated copper chloride samples was carried out using Shimadzu UV-2400PC SERIES with UV Probe (Shimadzu, JAPAN). The spectrum was recorded in the wavelength range of $190-800 \mathrm{~nm}$ using $1 \mathrm{~cm}$ quartz cell having a slit width of $0.5 \mathrm{~nm}$. The absorbance spectra (in the range of 0.2 to 0.9 ) and wavelength of maximum absorbance $\left(\lambda_{\max }\right)$ were recorded.

Fourier transform infrared (FT-IR) spectroscopy: FT-IR spectroscopy of copper chloride was performed on Spectrum ES Fourier transform infrared spectrometer (Perkin Elmer, USA) by using pressed $\mathrm{KBr}$ disk technique with the frequency array of 400$4000 \mathrm{~cm}^{-1}$. The technique uses $\sim 2 \mathrm{mg}$ of control sample and about $300 \mathrm{mg}$ of $\mathrm{KBr}$ as the diluent to form the pressed disk followed by running the sample in the spectrometer. The same procedure was used for the Biofield Energy Treated sample.

\section{Results and Discussion}

\section{Powder X-ray Diffraction (PXRD) analysis}

The PXRD diffractograms of control and Biofield Energy Treated samples of copper chloride are presented in (Figure 1). The diffractograms showed very sharp and intense peaks which depict that both the control and Biofield Energy Treated samples are crystalline in nature. Additionally, the PXRD data was collected

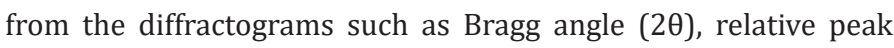
intensity (\%), FWHM, and were used for analyzing the crystallite size (G) of both the control and Biofield Energy Treated copper chloride, as mentioned in (Table 1). The Scherer equation [45] was used for the calculation of crystallite sizes across various planes. The PXRD diffractogram of the Control and Biofield Energy Treated samples showed highest peak intensity (100\%) at Bragg's angle

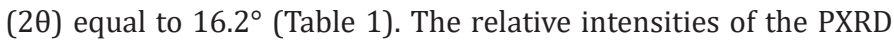
peaks at $2 \theta$ equal to $26.6^{\circ}, 28.8^{\circ}, 32.7^{\circ}, 34.0^{\circ}, 35.4^{\circ}, 38.0^{\circ}, 40.8^{\circ}$, $50.0^{\circ}, 54.4^{\circ}, 57.4^{\circ}$, and $68.6^{\circ}$ (Table 1 , entry $4-10$, and $13-16$ ) in the Biofield Energy Treated sample were significantly increased 
in the range from $2.24 \%$ to $153.49 \%$ compared to the control sample. It was presumed that the molecules of neighboring plane got oriented in these planes after the Biofield Energy Treatment. Consequently, the relative intensities of the PXRD peaks at $2 \theta$ equal to $21.9^{\circ}, 23.7^{\circ}, 44.8^{\circ}$, and $49.1^{\circ}$ (Table 1 , entry 3,6 , and 9-11) in the Biofield Energy Treated sample were significantly decreased in the range from $3.70 \%$ to $27.67 \%$ compared to the control sample, which also supports the above mentioned phenomenon, i.e., the molecules of these planes got oriented towards the other planes, thereby decreased intensity. Besides, the data also revealed that the crystallite sizes of the Biofield Energy Treated samples of copper chloride at $2 \theta$ equal to nearly $23.7^{\circ}, 32.7^{\circ}, 54.4^{\circ}$, and $68.6^{\circ}$ (Table 1 , entry $3,6,14$, and 16 ) were significantly decreased from $0.126 \%$ to $30.03 \%$ with respect to the control sample. However, the crystallite sizes of the Biofield Energy Treated sample at other Bragg's angle (Table 1, entry 1, 2, 4, 5, 7-13, and 15) showed slight alteration or remained unaltered as compared to the control sample. Also, the average crystallite size of the Biofield Energy Treated sample was decreased by $4.49 \%$ in comparison to the control sample. It is presumed that the Biofield Energy Treatment might produce some lattice strain within the molecular geometry, thereby causing the fracturing of grains into sub-grains and thus, decreased crystallite size of the Biofield Energy Treated copper chloride sample.

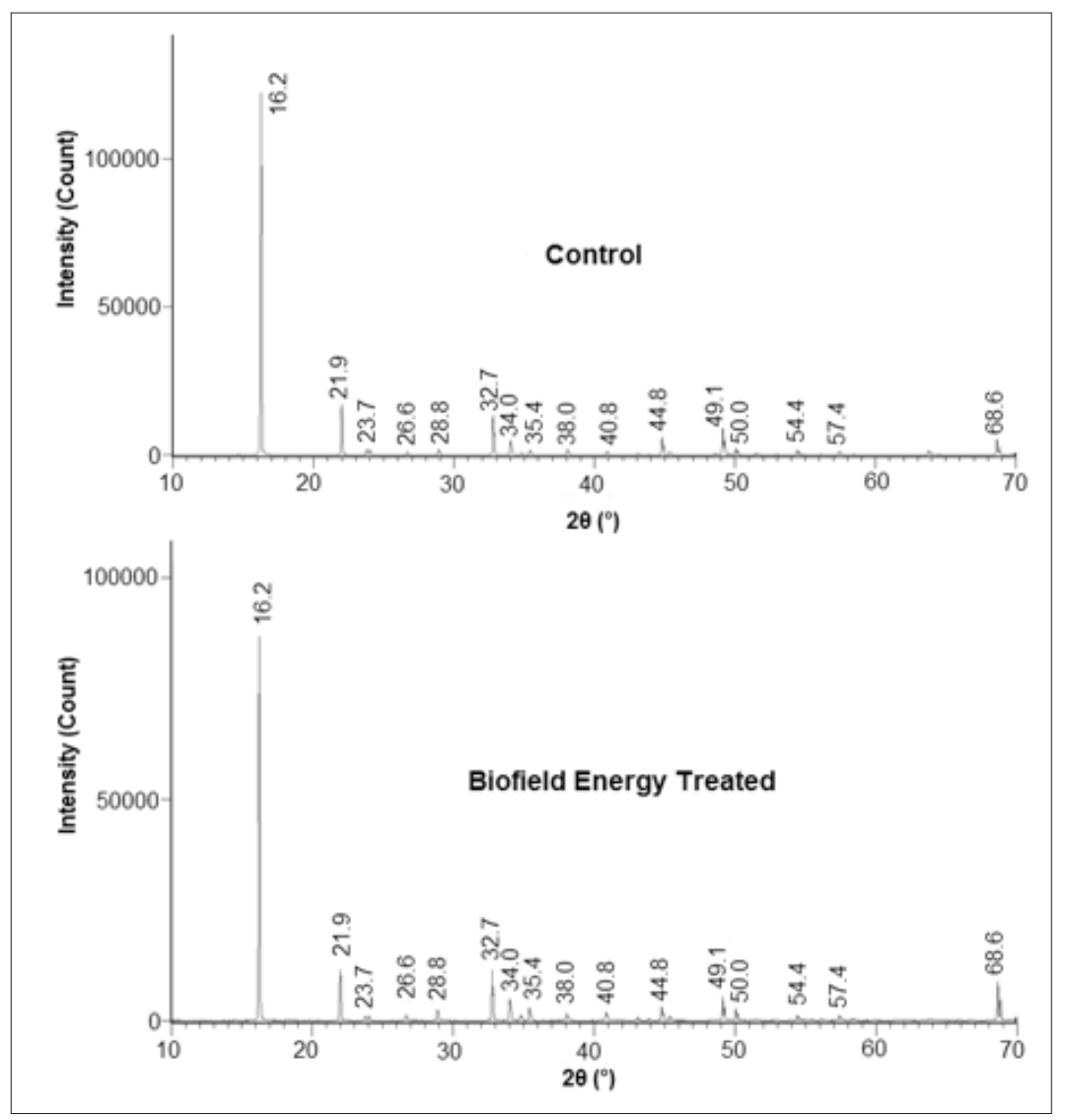

Figure 1: XRD diffractograms of the control and biofield energy treated copper chloride.

Table 1: PXRD data for the control and biofield energy treated copper chloride. adenotes the percentage change in the relative intensity of biofield energy treated sample with respect to the control sample; benotes the percentage change in the crystallite size of biofield energy treated sample with respect to the control sample.

\begin{tabular}{|c|c|c|c|c|c|c|c|}
\hline \multirow{2}{*}{ Entry No. } & \multirow{2}{*}{ Bragg Angle $\left({ }^{\circ} \mathbf{2 \theta}\right)$} & \multicolumn{3}{|c|}{ Relative Peak Intensity (\%) } & \multicolumn{3}{c|}{ Crystallite Size (G, nm) } \\
\cline { 3 - 9 } & & Control & Treated & \%Change $^{\mathbf{a}}$ & Control & Treated & \%Change \\
\hline 1 & 16.2 & 100 & 100 & 0 & 49.68 & 49.68 & 0 \\
\hline 2 & 21.9 & 13.52 & 13.02 & -3.7 & 35.06 & 35.06 & 0 \\
\hline 3 & 23.7 & 1.51 & 1.16 & -23.18 & 50.26 & 35.17 & -30.03 \\
\hline 4 & 26.6 & 0.76 & 1.35 & 77.63 & 50.55 & 50.54 & 0 \\
\hline 5 & 28.8 & 1.41 & 2.56 & 81.56 & 50.79 & 50.79 & 0 \\
\hline
\end{tabular}




\begin{tabular}{|c|c|c|c|c|c|c|c|}
\hline 6 & 32.7 & 10.87 & 13.03 & 19.87 & 73.54 & 58.83 & -20 \\
\hline 7 & 34 & 3.78 & 5.42 & 43.39 & 49.19 & 49.18 & -0.01 \\
\hline 8 & 35.4 & 1.28 & 3.13 & 144.53 & 59.25 & 59.25 & 0 \\
\hline 9 & 38 & 1.61 & 1.88 & 16.77 & 59.71 & 59.7 & -0.01 \\
\hline 10 & 40.8 & 0.86 & 2.18 & 153.49 & 60.24 & 60.23 & -0.01 \\
\hline 11 & 44.8 & 4.92 & 3.56 & -27.64 & 61.06 & 61.05 & -0.01 \\
\hline 12 & 49.1 & 7.2 & 6.3 & -12.5 & 62.08 & 62.07 & -0.01 \\
\hline 13 & 50 & 1.99 & 3.13 & 57.29 & 62.31 & 62.3 & -0.004 \\
\hline 14 & 54.4 & 1.34 & 1.37 & 2.24 & 63.49 & 52.9 & -16.678 \\
\hline 15 & 57.4 & 0.89 & 1.29 & 44.94 & 45.99 & 45.98 & -0.01 \\
\hline 16 & 68.6 & 4.13 & 10.13 & 145.28 & 68.48 & 68.39 & -0.126 \\
\hline
\end{tabular}

The significant alterations in the crystallite size and relative intensities of the Biofield Energy Treated sample indicated the modification in the crystal morphology as compared to the control sample. Some studies reported that such alteration in the crystal morphology due to changes in the relative intensities and crystallite size might indicate the presence of different polymorphs of the compounds [46]. Hence, the Biofield Energy Treatment probably introduced a new polymorphic form of the copper chloride with the help of energy transfer process [47]. Besides, any alteration in the crystal morphology might impact the dissolution and bioavailability profile of pharmaceutical/nutraceutical compound [48,49]. Thus, the Biofield Energy Treatment might improve the bioavailability profile of copper chloride.

\section{Thermal Gravimetric Analysis (TGA) / Differential Thermogravimetric analysis (DTG)}

The TGA/DTG analysis is used to determine the thermal stability of the samples with the help of the thermograms of the control and Biofield Energy Treated copper chloride (Figures 2 \& 3). Also, the TGA and DTG data for the control and Biofield Energy Treated samples are mentioned in (Table 2). Some previous studies reported the thermal degradation of copper chloride dihydrate salt in various steps, as the compound loses its two water molecules in two steps in the temperature range of 66 to $132{ }^{\circ} \mathrm{C}$ at $10{ }^{\circ} \mathrm{C} / \mathrm{min}$ heating rate under a dynamic nitrogen atmosphere [50]. The TGA thermograms of the control and Biofield Energy Treated copper chloride also revealed three steps of thermal degradation (Figure 2 ). The analysis showed that in the $1^{\text {st }}$ and $3^{\text {rd }}$ step of degradation, the percentage weight loss was slightly increased by $0.33 \%$ and $3.64 \%$ in the Biofield Energy Treated copper chloride, respectively; while it was significantly reduced by $17.79 \%$ in the $2^{\text {nd }}$ step of degradation, as compared to the control sample (Table 2). Moreover, the overall weight loss after thermal degradation in the Biofield Energy Treated sample was increased by $1.45 \%$, compared with the control sample. It revealed that there is significant alteration in the thermal stability of the Biofield Energy Treated sample as compared to the control sample. Besides, the DTG thermograms of the control and Biofield Energy Treated samples (Figure 3) exhibited three peaks. The Tmax values in the $1^{\text {st }}, 2^{\text {nd }}$, and $3^{\text {rd }}$ peaks of the Biofield Energy Treated sample were increased by $6.92 \%$, $1.32 \%$, and $1.77 \%$, respectively, compared with the control sample (Table 2). Overall, TGA/DTG revealed that the maximum thermal degradation temperature of the Biofield Energy Treated copper chloride was significantly improved along with notable alteration in the thermal stability, compared to the control sample.

Table 2: Thermal degradation steps of the control and biofield energy treated copper. $\mathrm{T}_{\max }$ : Maximum thermal degradation temperature, *denotes the percentage change in the weight loss of biofield energy treated sample with respect to the control sample.

\begin{tabular}{|c|c|c|c|c|c|c|c|}
\hline \multirow[t]{2}{*}{ Sample } & \multicolumn{4}{|c|}{$\begin{array}{c}\text { TGA } \\
\text { Weight Loss (\%) }\end{array}$} & \multicolumn{3}{|c|}{$\begin{array}{c}\text { DTG } \\
\mathrm{T}_{\max }\left({ }^{\circ} \mathrm{C}\right)\end{array}$} \\
\hline & $\mathbf{1}^{\text {st }}$ Step & $2^{\text {nd }}$ Step & $3^{\text {rd }}$ Step & Total & $1^{\text {st }}$ Step & $2^{\text {nd }}$ Step & $3^{\text {rd }}$ Step \\
\hline Control & 21.22 & 6.69 & 69.44 & 97.35 & 93.7 & 418.87 & 560.44 \\
\hline Biofield Energy Treated & 21.29 & 5.5 & 71.97 & 98.76 & 100.18 & 424.38 & 570.37 \\
\hline$\%$ change* & 0.33 & -17.79 & 3.64 & 1.45 & 6.92 & 1.32 & 1.77 \\
\hline
\end{tabular}




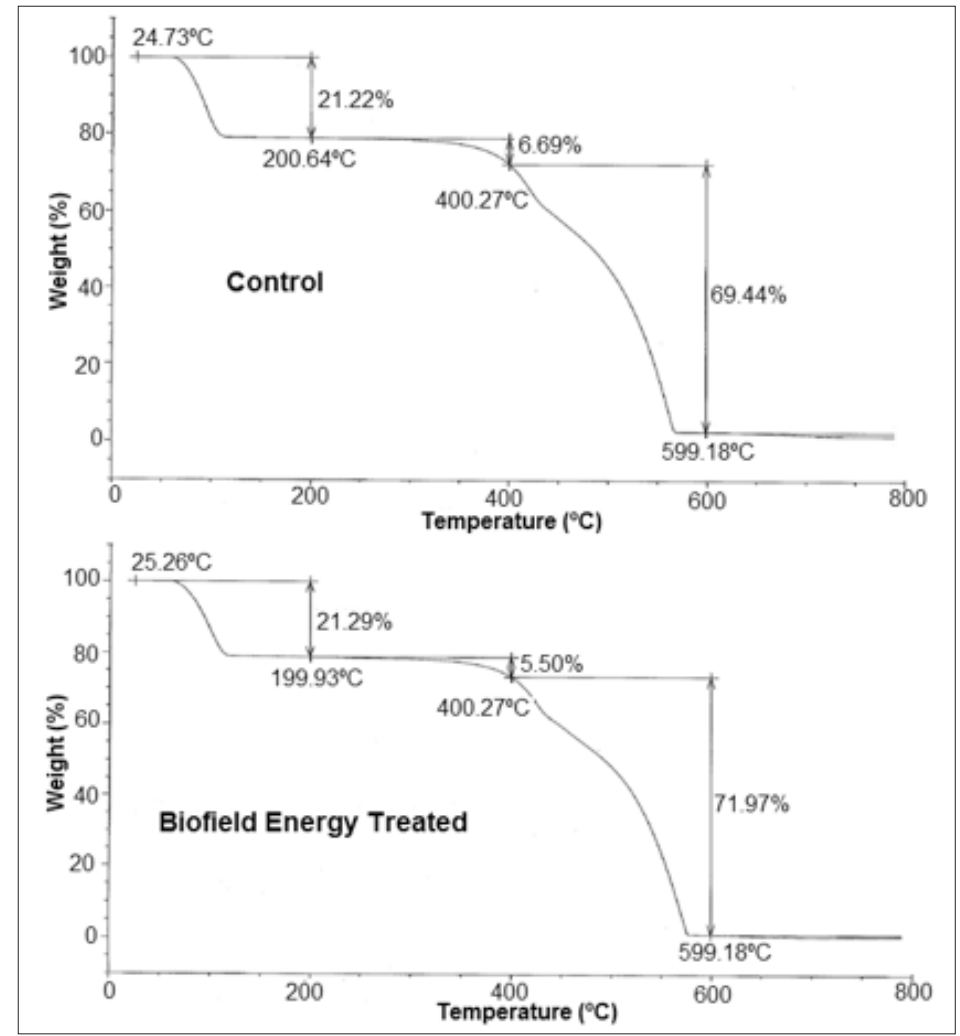

Figure 2: TGA thermograms of the control and biofield energy treated copper chloride.

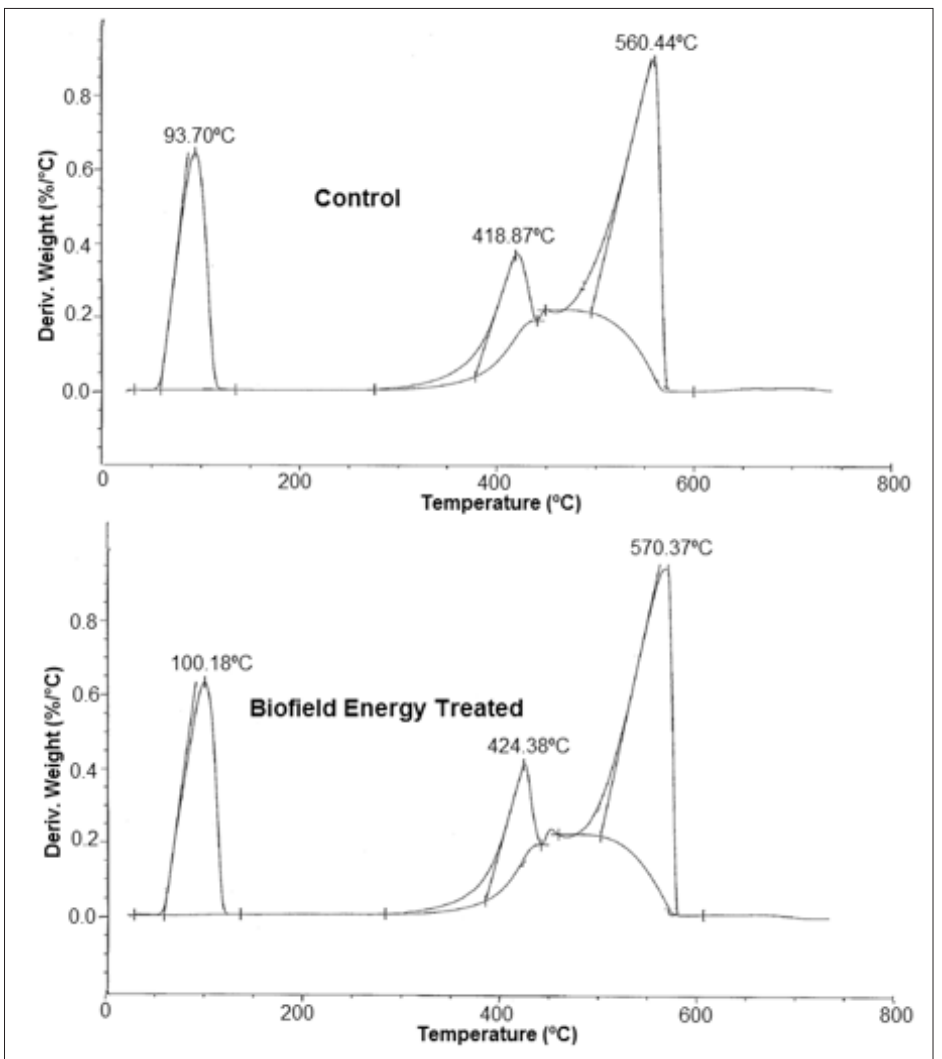

Figure 3: DTG thermograms of the control and biofield energy treated copper chloride. 


\section{Differential Scanning Calorimetry (DSC) analysis}

The DSC thermograms of the control and Biofield Energy Treated samples of copper chloride are shown in (Figure 4) and analysis is presented in (Table 3). The DSC thermograms of the control and Biofield Energy Treated samples of copper chloride (Figure 4) exhibited broad endothermic and sharp exothermic peaks. The DSC curve of the control sample showed a broad endothermic peak at $131.73{ }^{\circ} \mathrm{C}$ which showed the melting point of copper (II) chloride dihydrate [50]. Similarly, the Biofield Energy treated sample showed the melting point at $130.01{ }^{\circ} \mathrm{C}$, which was slightly decreased by $1.31 \%$ compared as the control sample (Table 3). However, the latent heat of fusion $(\Delta \mathrm{H})$ of the Biofield Energy Treated copper chloride was significantly reduced by $3.78 \%$ compared to the control sample. It showed that the Biofield Energy Treated copper chloride needed less energy in the form of $\Delta \mathrm{H}$ to undergo the whole process of melting after the Biofield Energy Treatment. Some scientific studies reported the decomposition of copper (II) chloride dihydrate above $300^{\circ} \mathrm{C}$ along with the release of chlorine gas [51]. In this study, the control sample showed a sharp exothermic peak at $358.72{ }^{\circ} \mathrm{C}$, whereas the Biofield Energy Treated sample showed this peak at $391.44{ }^{\circ} \mathrm{C}$, which were attributed to the decomposition of the copper (II) chloride dihydrate. The decomposition temperature of the Biofield Energy Treated copper chloride was significantly increased by $9.12 \%$ with a significant reduction of the enthalpy of decomposition by $43.45 \%$ compared with the control sample. The DSC results suggested that the thermal stability of the Biofield Energy Treated sample was significantly improved compared with the control sample (Table 2). Previously, our group reported the alteration in the melting point and latent heat of fusion in lead and tin powder after the Biofield Energy Treatment [27]. Thus, it is possible that the Biofield Energy Treatment might alter the potential and kinetic energy of the copper chloride molecules that possibly resulted in the alteration of $\Delta \mathrm{H}$ and melting/decomposition temperature in the Biofield Energy Treated sample, as compared to the control sample.

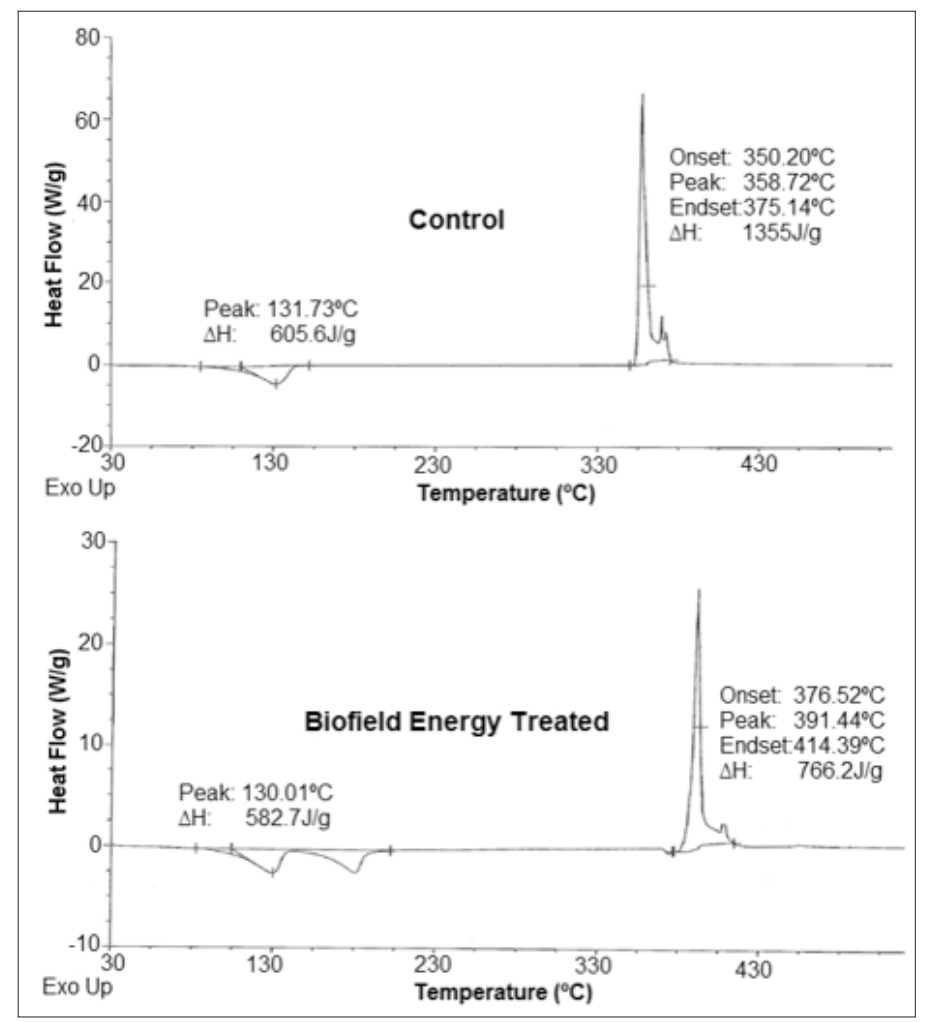

Figure 4: DSC thermograms of the control and biofield energy treated copper chloride.

Table 3: Comparison of DSC data between the control and biofield energy treated copper chloride.

\begin{tabular}{|c|c|c|c|c|}
\hline \multirow{2}{*}{ Sample } & \multicolumn{2}{|c|}{ Melting/Decomposition Temperature $\left({ }^{\circ} \mathrm{C}\right)$} & \multicolumn{2}{|c|}{$\Delta \mathrm{H}(\mathrm{J} / \mathrm{g})$} \\
\hline & $1^{\text {st }}$ Peak & $2^{\text {nd }}$ Peak & $1^{\text {st }}$ Peak & $2^{\text {nd }}$ Peak \\
\hline Control & 131.73 & 358.72 & 605.6 & 1355 \\
\hline Biofield Energy Treated & 130.01 & 391.44 & 582.7 & 766.2 \\
\hline$\%$ Change* $^{*}$ & -1.31 & 9.12 & -3.78 & -43.45 \\
\hline
\end{tabular}




\section{Ultraviolet-visible spectroscopy (UV-Vis) analysis}

The UV-visible spectra of both, the control and Biofield Energy Treated copper chloride samples are presented in (Figure 5). The UV spectra of both, the control and Biofield Energy Treated samples showed the maximum absorbance $\left(\lambda_{\max }\right)$ at $866 \mathrm{~nm}$.
Thus, it represents no significant alteration in the absorbance maxima between the control and Biofield Energy Treated sample. It depicted that there might not be any significant change in the electronic transitions between highest occupied molecular orbital and lowest unoccupied molecular orbital, induced by the Biofield Energy Treatment.

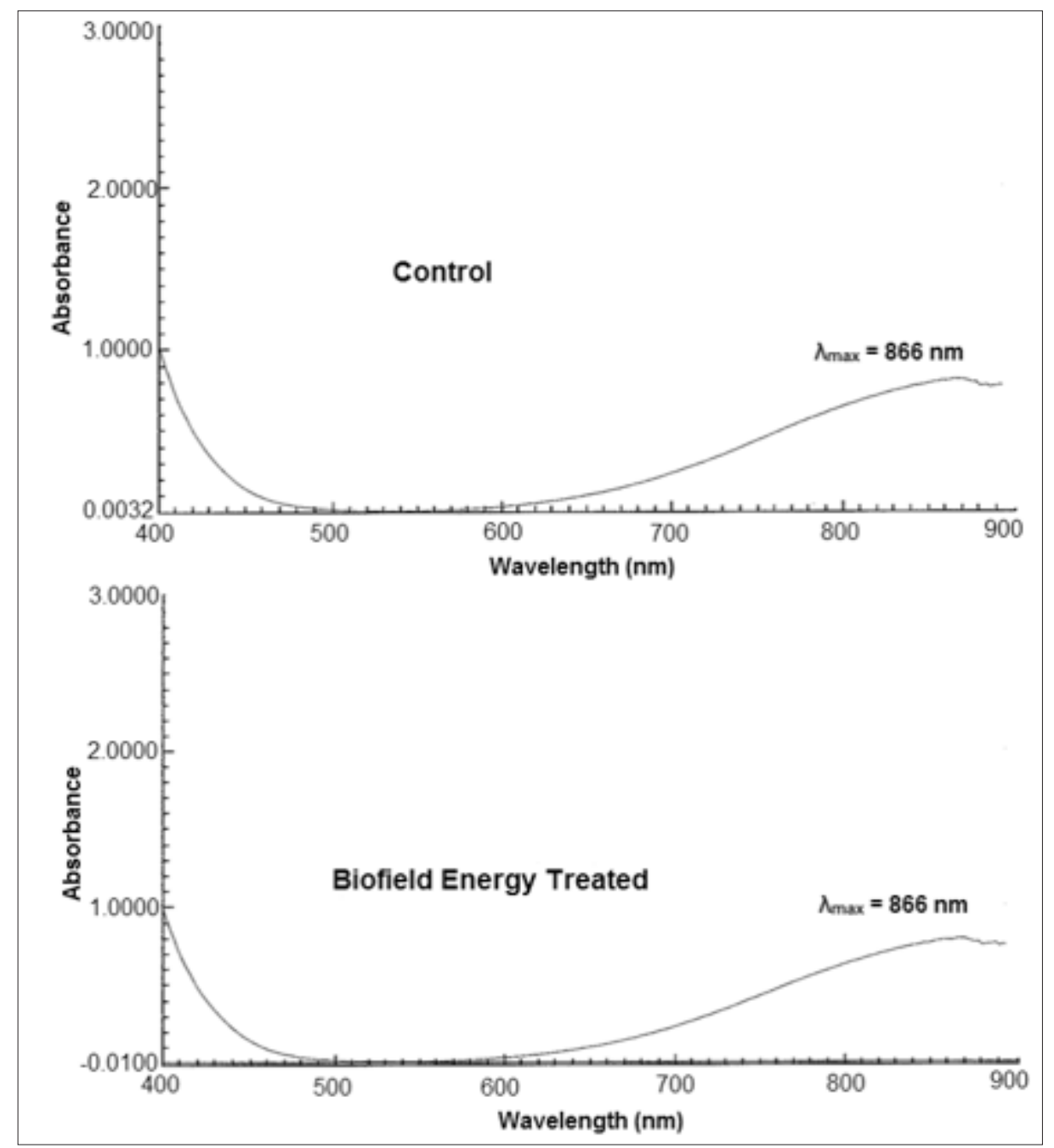

Figure 5: UV-vis spectra of the control and biofield energy treated copper chloride.

\section{Fourier Transform Infrared (FT-IR) spectroscopy}

The FT-IR spectra of control and Biofield Energy Treated samples of copper chloride are given in (Figure 6). The FT-IR spectra of both the control and Biofield Energy Treated copper chloride showed the clear stretching and bending peaks in the functional group as well as the fingerprint region. The control spectrum showed peaks at $2923 \mathrm{~cm}^{-1}$ and $2854 \mathrm{~cm}^{-1}$ which were assigned to the aliphatic C-H stretching. Similar peaks were present in the spectrum of the Biofield Energy Treated sample at $2924 \mathrm{~cm}^{-1}$ and $2854 \mathrm{~cm}^{-1}$. Besides, there were stretching frequency at $1377 \mathrm{~cm}^{-}$
${ }^{1}$ and $1460 \mathrm{~cm}^{-1}$ in fingerprint region of both control and Biofield Energy Treated samples of Copper Chloride. However, the peaks at 892 and $1154 \mathrm{~cm}^{-1}$ in the control spectrum were not observed in the spectrum of the Biofield Energy Treated sample. Also, the peak at $1588 \mathrm{~cm}^{-1}$ in the control sample spectrum was shifted to higher frequency at $1601 \mathrm{~cm}^{-1}$ in the spectrum of the Biofield Energy Treated sample. Overall, the FT-IR studies revealed that the Biofield Energy Treated copper chloride might got impacted at the atomic level due to the Biofield Energy Treatment, which may further affect the structural and bonding properties such as, bond strength, rigidity, and the stability of compound, etc. 


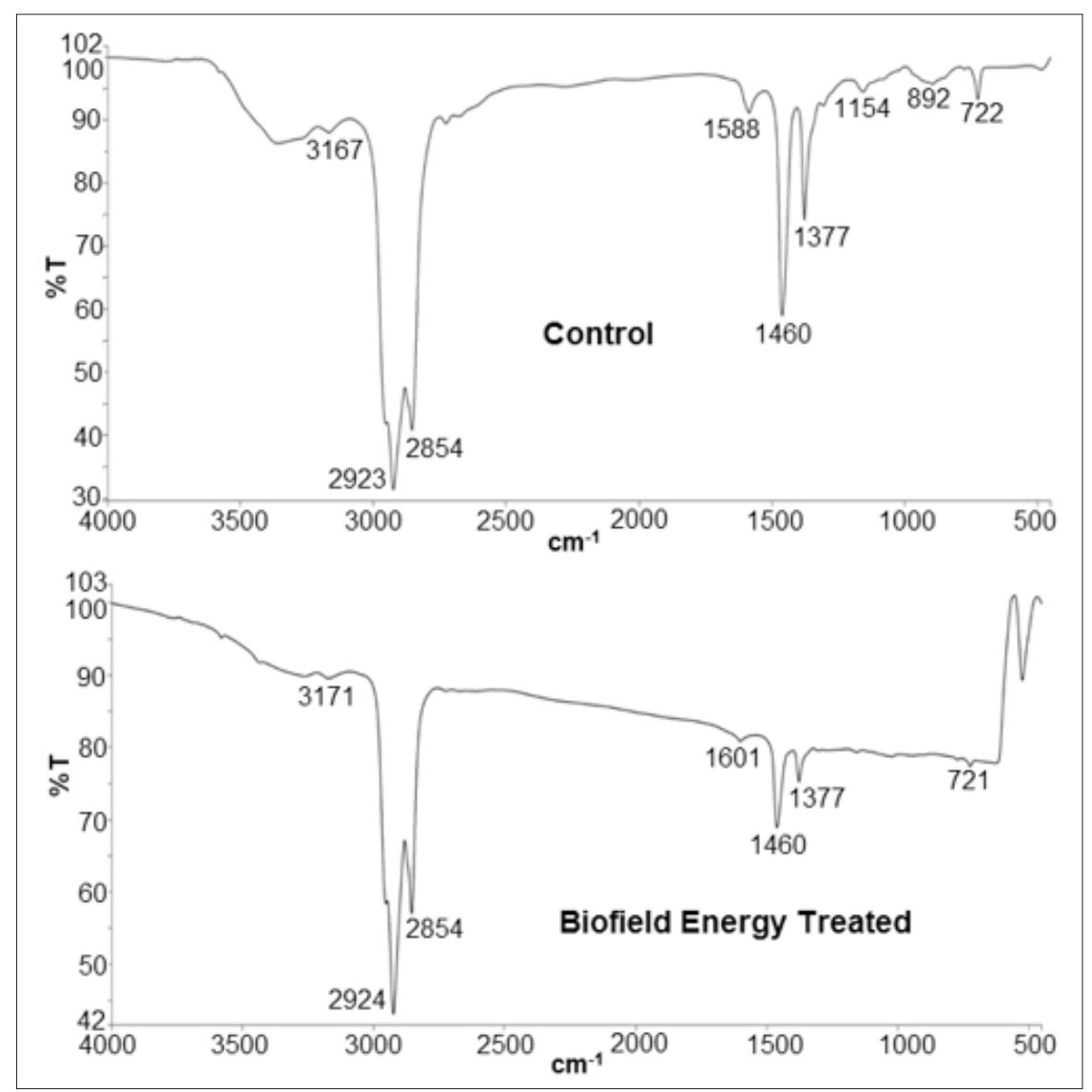

Figure 6: FT-IR spectra of the control and biofield energy treated copper chloride.

\section{Conclusion}

The overall analysis concluded that The Trivedi Effect ${ }^{\circledR}$ - Energy of Consciousness Healing Treatment has the significant impact on the physical, thermal, and spectral properties of copper chloride. The PXRD analysis revealed that the relative peak intensities of the characteristic peaks of Biofield Energy Treated sample showed alteration in the range from $-27.67 \%$ to $153.49 \%$, as compared to the control sample. Similarly, the crystallite sizes of the Biofield Field Energy Treated sample across various planes got decreased from $0.126 \%$ to $30.03 \%$ along with $4.49 \%$ decrease in the average crystallite size, compared with the control sample. The alterations in the crystallite size and relative peak intensities of the Biofield Energy Treated copper chloride suggested the disturbance in the crystallinity and regular pattern of the atoms across those planes that might occur due to the Biofield Energy Treatment. Moreover, the TGA analysis revealed three steps of thermal degradation in which, the $1^{\text {st }}$ and $3^{\text {rd }}$ step of degradation of the Biofield Energy Treated sample showed slight increase in percentage weight loss by $0.33 \%$ and $3.64 \%$, respectively; while it was significantly reduced by $17.79 \%$ in the $2^{\text {nd }}$ step of degradation as compared to the control sample. Additionally, the total weight loss of the Biofield Energy Treated sample was increased by $1.45 \%$. Besides, the DTG analysis revealed increase in the $\mathrm{T}_{\max }$ values of the $1^{\text {st }}, 2^{\text {nd }}$, and $3^{\text {rd }}$ peaks of the Biofield Energy Treated sample by $6.92 \%, 1.32 \%$, and $1.77 \%$, respectively, compared with the control sample. The thermal analysis showed significant increase in the thermal degradation of the Biofield Energy Treated copper chloride with altered thermal stability. The DSC analysis of both the samples showed endothermic and exothermic peaks. The data represented slight decrease in the melting point of the Biofield Energy Treated sample (1.31\%) along with $3.78 \%$ decrease in $\Delta H$ than the control sample. It showed that the Biofield Energy Treated sample requires less energy during the process of melting, as compared to the control sample. Also, the analysis revealed $9.12 \%$ increase in the decomposition temperature of the treated sample along with $43.45 \%$ reduction in the $\Delta \mathrm{H}$, as compared to the control sample. The whole analysis indicated the increased thermal stability of the Biofield Energy Treated copper chloride after the Biofield Energy Treatment. Nevertheless, the FT-IR spectrum of the Biofield Energy Treated sample showed alterations in the wave number of the characteristic peaks, as the peak at 892 and $1154 \mathrm{~cm}^{-1}$ in the control spectra were diminished in the spectrum of Biofield Energy Treated sample. Also, the peak at $1588 \mathrm{~cm}^{-1}$ in the control sample spectra was shifted to higher frequency at $1601 \mathrm{~cm}^{-1}$ in the spectra of Biofield Energy Treated sample. 
Overall, the current study showed the significant impact of The Trivedi Effect ${ }^{\circledR}$-The Energy of Consciousness Healing Treatment on the physical, thermal and spectral properties of copper chloride. The Biofield Energy Treatment might create a new polymorphic form of the compound having reduced crystallite size and altered crystallinity. Also, the study indicated the potential of The Trivedi Effect $^{\circledR}$ in enhancing the thermal stability and altering the other properties of drugs which may prove to be helpful in designing a better nutraceutical and/or pharmaceutical formulations with enhanced bioavailability, stability and safety profile. The Biofield Energy Treated copper chloride may help in providing better therapeutic response against the copper deficiency and related diseases such as leukopenia, anemia, neutropenia, depressed ceruloplasmin levels, immunological disorders, cardiovascular disease, etc.

\section{Acknowledgement}

The authors are grateful to GVK Biosciences Pvt. Ltd., Trivedi Science, Trivedi Global, Inc., Trivedi Testimonials, and Trivedi Master Wellness for their assistance and support during this work.

\section{References}

1. Linder MC, Hazegh Azam M (1996) Copper biochemistry and molecular biology. Am J Clin Nutr 63(5): 797S-811S.

2. Uauy R, Olivares M, Gonzalez M (1998) Essentiality of copper in humans. Am J Clin Nutr 67(5): 952S-959S.

3. Vashchenko G, MacGillivray RT (2013) Multi-copper oxidases and human iron metabolism. Nutrients 5(7): 2289-2313.

4. Harris ED (1997) Copper. In: O Dell BL, Sunde RA, (Eds.), Handbook of nutritionally essential minerals. New York, USA.

5. El Maalam K, Ben Ali M, EI Moussaoui H, Mounkachi O, Hamedouna M, et al. (2015) Magnetic properties of tin ferrites nanostructures doped with transition metal. Journal of Alloys and Compounds 622: 761-764.

6. Masrour R, Jabar A, Khlif H, Ben Jemaa F, Ellouze M, et al. (2017) Experiment, mean field theory and monte carlo simulations of the magnetocaloric effect in $\mathrm{La}_{0.67} \mathrm{Ba}_{0.22} \mathrm{SrO}_{.11} \mathrm{MnO}_{3}$ compound. Solid State Communications 268: 64-69.

7. Masrour R, Hlil EK, Hamedoun M, Benyoussef A, Boutahar A, et al (2015) Antiferromagnetic spintronics of $\mathrm{Mn}_{2} \mathrm{Au}$ : An experiment, first principle, mean field and series expansions calculations study. Journal of Magnetism and Magnetic Materials 393: 600-603.

8. Prohaska JR (2012) Copper. In: Erdman JW, Macdonald IA, Zeisel SH, (Eds.), Present Knowledge in Nutrition $\left(10^{\text {th }}\right.$ edn), Ames: WileyBlackwell, USA.

9. Jones AA, DiSilvestro RA, Coleman M, Wagner TL (1997) Copper supplementation of adult men: Effects on blood copper enzyme activities and indicators of cardiovascular disease risk. Metabolism 46(12): 13801383.

10. Thackeray EW, Sanderson SO, Fox JC, Kumar N (2011) Hepatic iron overload or cirrhosis may occur in acquired copper deficiency and is likely mediated by hypoceruloplasminemia. J Clin Gastroenterol 45(2): 153-158.

11. Turnlund JR (2006) Copper. In: Shils ME, Shike M, Ross AC, Caballero B, Cousins RJ (Eds.), Modern Nutrition in Health and Disease (10 $10^{\text {th }}$ edn), Philadelphia: Lippincott Williams \& Wilkins, USA.
12. Klevay LM (1998) Lack of a recommended dietary allowance for copper may be hazardous to your health. J Am Coll Nutr 17(4): 322-326.

13. Hendler SS, Rorvik DR (2001) PDR for Nutritional Supplements. Montvale: Medical Economics Company, Inc, USA.

14. Jonas WB, Crawford CC (2003) Science and spiritual healing: A critical review of spiritual healing, "energy" medicine, and intentionality. Altern Ther Health Med 9(2): 56-61.

15. Ernst E, Pittler MH, Wider B, Boddy K (2008) Oxford Handbook of Complementary Medicine. Oxford University Press, UK.

16. Stenger VJ (1999) Bioenergetic Fields. The scientific review of alternative medicine 3. USA.

17. The US National Centre for Complementary and Alternative Medicine (2009) CAM basics. What is complementary and alternative medicine? Department of Health and Human Services. USA.

18. Anderson JG, Taylor AG (2011) Effects of healing touch in clinical practice. A systematic review of randomized clinical trials. J Holist Nurs 29(3): 221-228.

19. Rubik B (2002) The biofield hypothesis: Its biophysical basis and role in medicine. J Altern Complement Med 8(6): 703-717.

20.Zahra M, Farsi M (2009) Biofield therapies: Biophysical basis and biological regulations. Complement Ther Clin Pract 15(1): 35-37.

21. Koithan M (2009) Introducing complementary and alternative therapies. J Nurse Pract 5(1): 18-20.

22. Trivedi MK, Branton A, Trivedi D, Nayak G, Bairwa K, et al. (2015) Impact of biofield treatment on spectroscopic and physicochemical properties of p-nitroaniline. Insights in Analytical Electrochemistry 1: 1-8.

23. Trivedi MK, Branton A, Trivedi D, Nayak G, Bairwa K, et al. (2015) Physical, thermal and spectroscopical characterization of biofield treated triphenylmethane: An impact of biofield treatment. J Chromatogr Sep Tech 6: 292.

24. Trivedi MK, Branton A, Trivedi D, Nayak G, Bairwa K, et al. (2015) Physicochemical and spectroscopic characteristics of biofield treated p-chlorobenzophenone. American Journal of Physical Chemistry 4(6): 48-57.

25. Trivedi MK, Patil S, Shettigar H, Singh R, Jana S (2015) An impact of biofield treatment on spectroscopic characterization of pharmaceutical compounds. Mod Chem Appl 3: 159.

26. Trivedi MK, Branton A, Trivedi D, Nayak G, Bairwa K, et al. (2015) Spectroscopic characterization of disulfiram and nicotinic acid after biofield treatment. J Anal Bioanal Tech 6: 265.

27. Trivedi MK, Branton A, Trivedi D, Nayak G, Balmer AJ, et al. (2017) Evaluation of physicochemical, thermal, structural, and behavioral properties of magnesium gluconate treated with energy of consciousness (The Trivedi Effect ${ }^{\circledR}$ ). Journal of Drug Design and Medicinal Chemistry 3(1): 5-17.

28. Trivedi MK, Tallapragada RM, Branton A, Trivedi D, Nayak G, et al. (2015) Physical, atomic and thermal properties of biofield treated lithium powder. J Adv Chem Eng 5: 136.

29. Trivedi MK, Nayak G, Patil S, Tallapragada RM, Latiyal O (2015) Impact of biofield treatment on physical, structural and spectral properties of antimony sulfide. Ind Eng Manage 4: 165.

30. Trivedi MK, Nayak G, Patil S, Tallapragada RM, Latiyal O (2015) Studies of the atomic and crystalline characteristics of ceramic oxide nano powders after bio field treatment. Ind Eng Manage 4: 161.

31. Trivedi MK, Branton A, Trivedi D, Nayak G, Bairwa K, Jana S (2015) Effect of biofield treatment on physical, thermal, and spectral properties of 
SFRE 199-1 mammalian cell culture medium. Advances in Biochemistry 3: 77-85.

32. Trivedi MK, Branton A, Trivedi D, Nayak G, Bairwa K, et al. (2015) Physicochemical and spectroscopic properties of biofield energy treated protose. American Journal of Biomedical and Life Sciences 3(6): 104110.

33. Trivedi MK, Branton A, Trivedi D, Nayak G, Mondal SC, et al. (2015) Morphological characterization, quality, yield and DNA fingerprinting of biofield energy treated alphonso mango (Mangifera indica L.). Journal of Food and Nutrition Sciences 3: 245-250.

34. Trivedi MK, Branton A, Trivedi D, Nayak G, Gangwar M, et al. (2015) Agronomic characteristics, growth analysis, and yield response of biofield treated mustard, cowpea, horse gram, and groundnuts. International Journal of Genetics and Genomics 3(6): 74-80.

35. Kinney JP, Trivedi MK, Branton A, Trivedi D, Nayak G, et al. (2017) Overall skin health potential of the biofield energy healing based herbo mineral formulation using various skin parameters. American Journal of Life Sciences 5(2): 65-74.

36. Dodon J, Trivedi MK, Branton A, Trivedi D, Nayak G, et al. (2017) The study of biofield energy treatment based herbomineral formulation in skin health and function. American Journal of Bio Science 5(3): 42-53.

37. Trivedi MK, Patil S, Shettigar H, Gangwar M, Jana S (2015) In vitro evaluation of biofield treatment on cancer biomarkers involved in endometrial and prostate cancer cell lines. J Cancer Sci Ther 7(7): 253257.

38. Trivedi MK, Patil S, Shettigar H, Mondal SC, Jana S (2015) An impact of biofield treatment: Antimycobacterial susceptibility potential using BACTEC 460/MGIT-TB system. Mycobact Dis 5: 189.

39. Trivedi MK, Branton A, Trivedi D, Nayak G, Mondal SC, et al. (2015) Antibiogram of biofield-treated Shigella boydii: Global burden of infections. Science Journal of Clinical Medicine 4(6): 121-126.

40. Trivedi MK, Branton A, Trivedi D, Nayak G, Saikia G, et al. (2015) Quantitative determination of isotopic abundance ratio of ${ }^{13} \mathrm{C},{ }^{2} \mathrm{H}$, and ${ }^{18} \mathrm{O}$ in biofield energy treated ortho and meta toluic acid isomers. American Journal of Applied Chemistry 3(6): 217-223.

41. Trivedi MK, Branton A, Trivedi D, Nayak G, Saikia G, et al. (2015) Characterization of physico-chemical and spectroscopic properties of biofield energy treated 4-bromoacetophenone. American Journal of Physical Chemistry 4(4): 30-37.

42. Trivedi MK, Branton A, Trivedi D, Nayak G, Saikia G, et al. (2015) Thermal, spectroscopic and chromatographic characterization of biofield energy treated benzophenone. Science Journal of Analytical Chemistry 3(6): 109-114.

43. Trivedi MK, Branton A, Trivedi D, Nayak G, Saikia G, et al. (2015) Investigation of isotopic abundance ratio of biofield treated phenol derivatives using gas chromatography-mass spectrometry. J Chromatograph Separat Techniq S6: 003.

44. Trivedi MK, Branton A, Trivedi D, Nayak G, Plikerd WD, et al. (2017) A systematic study of the biofield energy healing treatment on physicochemical, thermal, structural, and behavioral properties of iron sulphate. International Journal of Bioorganic Chemistry 2(3): 135-145.

45. Langford JI, Wilson AJC (1978) Scherrer after sixty years: A survey and some new results in the determination of crystallite size. J Appl Cryst 11(2): 102-113.

46. Trivedi MK, Branton A, Trivedi D, Nayak G, Lee AC, et al. (2017) Investigation of physicochemical, spectral, and thermal properties of sodium selenate treated with the energy of consciousness (The Trivedi Effect $^{\circledR}$ ). American Journal of Life Sciences 5(1): 27-37.

47. Raza K, Kumar P, Ratan S, Malik R, Arora S (2014) Polymorphism: The phenomenon affecting the performance of drugs. SOJ Pharm Pharm Sci 1: 10 .

48. Zhao Z, Xie M, Li Y, Chen A, Li G, et al. (2015) Formation of curcumin nanoparticles via solution-enhanced dispersion by supercritical $\mathrm{CO}_{2}$. Int J Nanomedicine 10: 3171-3181.

49. Blagden N, de Matas M, Gavan PT, York P (2007) Crystal engineering of active pharmaceutical ingredients to improve solubility and dissolution rates. Adv Drug Deliv Rev 59(7): 617- 630.

50. Mohamed MA, Halawy SA (1994) Non-isothermal kinetic and thermodynamic study for the dehydration of copper (II) chloride dihydrate and nickel chloride hexahydrate. J Thermal Anal 41: 147-159.

51. Wirtz MC (2008) Oven versus bunsen burner when heating copper (II) chloride dihydrate. J Chem Educ 85(10): 1345.

For possible submissions Click below: 